\title{
Successful Treatment of Respiratory Syncytial Virus Infection in an Immunocompromised Patient With Ribavirin
}

\author{
Wasey Ali Yadullahi Mir ${ }^{1}$, Dhan B. Shrestha ${ }^{1}$, Wajahath Rana ${ }^{2}$, Shravani Reddy Yelma Reddy ${ }^{3}$, Ayusha \\ Paudel $^{4}$, Larissa Verda ${ }^{1}$
}

1. Department of Internal Medicine, Mount Sinai Hospital, Chicago, USA 2. Department of Infectious Diseases, Mount Sinai Hospital, Chicago, USA 3. Department of Internal Medicine, SRM Medical College Hospital and Research Centre, Chennai, IND 4. Department of Emergency Medicine, Alka Hospital Pvt Ltd, Kathmandu, NPL

Corresponding author: Dhan B. Shrestha, medhan75@gmail.com

\begin{abstract}
Respiratory syncytial virus (RSV) is a frequent cause of respiratory tract infections in children. Still, it can also cause seasonal outbreaks affecting persons of all ages, especially those with comorbidities or immunocompromised states. Ribavirin is one of the two approved therapies for the treatment of RSV respiratory tract infections. Unfortunately, its aerosolized formulation has been approved only in children, and the oral formulation is not frequently used to treat the infection. However, ribavirin has demonstrated morbidity and mortality benefit in immunocompromised patients. A 70-year-old female had started chemotherapy for a diagnosis of B-cell acute lymphoblastic leukemia (B-ALL). She developed an upper respiratory tract infection (URTI) along with positive RSV status. We started her on oral ribavirin therapy, which had to be stopped after five days of treatment due to an acute hemolytic reaction. She was re-initiated on oral ribavirin after cessation of medication for seven days and showed improvement. Therefore, ribavirin can be used in immunocompromised patients with RSV infection under proper supervision.
\end{abstract}

Review began 07/19/2021 Review ended 07/25/2021 Published 08/06/2021

\section{(c) Copyright 2021}

Mir et al. This is an open access article distributed under the terms of the Creative Commons Attribution License CC-BY 4.0., which permits unrestricted use, distribution, and reproduction in any medium, provided the original author and source are credited.
Categories: Allergy/Immunology, Infectious Disease, Pulmonology

Keywords: respiratory syncytial virus, ribavirin, leukemia, respiratory tract infection, elderly

\section{Introduction}

Respiratory syncytial virus (RSV) is a single-stranded, negative-sense, enveloped RNA virus that commonly infects children worldwide [1]. It has now been recognized as a problem in the adult population, with significant mortality and morbidity in immunocompromised hosts [2]. The clinical manifestations of RSV infection in an immunocompromised individual depends on the degree of immunosuppression [2]. Ribavirin use has demonstrated effectiveness in preventing the progression of RSV infection from lowering respiratory tract infection [3]. Generally, inhaled ribavirin is used to treat RSV infection; however, we present a patient with newly diagnosed B-cell acute lymphoblastic leukemia (B-ALL) with RSV infection, which significantly benefited with oral ribavirin therapy.

\section{Case Presentation}

A 70-year-old female with a past medical history of hypertension and hyperlipidemia presented with a history of gastroesophageal reflux disease. She was taking amlodipine, pantoprazole, and atorvastatin. On admission, she presented with fatigue and weakness. The patient was afebrile and hemodynamically stable. Physical examination findings were unremarkable. Chest examination was normal, with no rales or wheezes. Cardiac and abdominal examinations were unremarkable. The patient had pancytopenia with hemoglobin of $11.8 \mathrm{gm} \%$, platelet count of 87000 per microlitre, and leukocyte count of 2200 per microlitre. The uric acid level was elevated to $6.8 \mathrm{mg} / \mathrm{dl}$.

A bone marrow biopsy was performed, which was positive for B-ALL. The patient was diagnosed with B-ALL, for which she was started on chemotherapeutic drugs. When on chemotherapy, she experienced generalized weakness, fatigue, and decreased appetite for three months. She also developed upper respiratory tract symptoms. The respiratory viral panel was sent, and it turned out to be positive for RSV the next day, and oral ribavirin was started immediately. The initial chest radiograph was negative for acute cardiopulmonary findings.

As the patient was immunocompromised with an RSV positive status, she was started on oral ribavirin 15-20 $\mathrm{mg} / \mathrm{kg}$ of body weight in three divided doses per day for 10 days. During the treatment course, hemoglobin dropped to $6.7 \mathrm{gm} \%$ on the fifth day of treatment. As a result, oral ribavirin was held. Following the discontinuation of the ribavirin and completing a round of chemotherapy, she became neutropenic with a temperature of $101^{\circ} \mathrm{F}$. She also developed hypoxemic respiratory failure with diffuse dense bilateral patchy infiltrates requiring intubation. 
She was promptly started on empiric and prophylactic antibiotics for immunosuppression. Blood cultures, sputum culture, serology for Histoplasma and Legionella, and bronchoscopy sample for pneumocystis were sent and found to be negative. However, a repeat respiratory panel was positive for RSV. After seven days without ribavirin, she was restarted on a new 10-day course of ribavirin. The patient showed recovery over few days and was extubated. She was discharged from the hospital following her recovery.

\section{Discussion}

Currently, no specific guidelines are available for the treatment of RSV in the adult population [4]. Ribavirin use has shown reduced mortality in RSV infection of adults [5]. It is available in three formulations: aerosolized, oral, and intravenous, out of which intravenous formulation is not approved by the Food and Drug Administration (FDA) [5]. FDA has approved the use of aerosolized ribavirin in infants and young children but not in adults [4,6]. Despite not being approved for adults, aerosolized ribavirin is predominantly used to treat RSV in adults $[7,8]$. However, a handful of studies have shown the benefit of oral ribavirin therapy [9-11].

Aerosolized ribavirin should be administered via a scavenging tent as it is teratogenic [9]. It is also associated with adverse effects like bronchospasm, which is undesirable in patients with RSV infection, nausea, and anemia [12]. It should be administered for six to eighteen hours daily, which is cumbersome [9]. Oral ribavirin is largely devoid of respiratory symptoms, with hemolytic anemia and gastrointestinal upset being the major side effects [13].

The cost of aerosolized and oral ribavirin therapy is also drastically different. For example, a single-day course of aerosolized ribavirin ran upwards of $\$ 11581$, while oral therapy was about $\$ 22$ in 2016 [12]. Therefore, the economic benefit during the choice of formulation when initiating therapy cannot be overlooked.

Due to the economic benefit and better respiratory symptoms profile, oral ribavirin therapy has started gaining prominence in clinical usage. In a small cohort of patients receiving oral ribavirin therapy at the University of California, San Francisco Medical Center, the use of oral ribavirin resulted in reduced expenditure without a significant increase in worse outcomes [12]. Another study reviewing the patients' outcome receiving oral ribavirin versus aerosolized formulation at the University of Texas MD Anderson Cancer Center showed no increased efficacy of aerosolized ribavirin. Therefore, it postulated that oral ribavirin might be a safe and effective alternative to the aerosolized formulation [5].

Patients receiving oral therapy experienced fewer side effects along with ease of administration. Therefore oral administration of ribavirin in adults can be considered in limited circumstances, as in this case [12].

\section{Conclusions}

RSV infection in an immunocompromised individual frequently results in lower respiratory tract infection. Ribavirin has demonstrated benefit in the morbidity and mortality of such patients. Although aerosolized ribavirin has been used for treatment purposes, oral formulation is gaining prominence in use due to its better safety profile and economic benefit. We report a case of successful treatment of RSV infection in an immunocompromised individual with the oral formulation of ribavirin.

\section{Additional Information \\ Disclosures}

Human subjects: Consent was obtained or waived by all participants in this study. Conflicts of interest: In compliance with the ICMJE uniform disclosure form, all authors declare the following: Payment/services info: All authors have declared that no financial support was received from any organization for the submitted work. Financial relationships: All authors have declared that they have no financial relationships at present or within the previous three years with any organizations that might have an interest in the submitted work. Other relationships: All authors have declared that there are no other relationships or activities that could appear to have influenced the submitted work.

\section{Acknowledgements}

We want to acknowledge our patient without whom this report would not have been possible. Additionally, we would like to thank all the treating healthcare personnel involved in patient care.

\section{References}

1. Wetzke M, Schwerk N: Respiratory syncytial virus infections. Pneumologe. 2019, 16:232-41. 10.1007/s10405-019-0252-8

2. Falsey AR, Walsh EE: Respiratory syncytial virus infection in adults. Clin Microbiol Rev. 2000, 13:371-84. 10.1128/CMR.13.3.371

3. Ghosh S, Champlin RE, Englund J, et al.: Respiratory syncytial virus upper respiratory tract illnesses in adult 
blood and marrow transplant recipients: combination therapy with aerosolized ribavirin and intravenous immunoglobulin. Bone Marrow Transplant. 2000, 25:751-5. 10.1038/sj.bmt.1702228

4. Nam HH, Ison MG: Respiratory syncytial virus infection in adults. BMJ. 2019, 366:15021. 10.1136/bmj.15021

5. Foolad F, Aitken SL, Shigle TL, Prayag A, Ghantoji S, Ariza-Heredia E, Chemaly RF: Oral versus aerosolized ribavirin for the treatment of respiratory syncytial virus infections in hematopoietic cell transplant recipients. Clin Infect Dis. 2019, 68:1641-9. 10.1093/cid/ciy760

6. Shah JN, Chemaly RF: Management of RSV infections in adult recipients of hematopoietic stem cell transplantation. Blood. 2011, 117:2755-63. 10.1182/blood-2010-08-263400

7. Shah DP, Ghantoji SS, Shah JN, et al.: Impact of aerosolized ribavirin on mortality in 280 allogeneic haematopoietic stem cell transplant recipients with respiratory syncytial virus infections. J Antimicrob Chemother. 2013, 68:1872-80. 10.1093/jac/dkt111

8. Boeckh M, Englund J, Li Y, et al.: Randomized controlled multicenter trial of aerosolized ribavirin for respiratory syncytial virus upper respiratory tract infection in hematopoietic cell transplant recipients. Clin Infect Dis. 2007, 44:245-9. 10.1086/509930

9. Gorcea CM, Tholouli E, Turner A, Saif M, Davies E, Battersby E, Dignan FL: Effective use of oral ribavirin for respiratory syncytial viral infections in allogeneic haematopoietic stem cell transplant recipients. J Hosp Infect. 2017, 95:214-7. 10.1016/j.jhin.2016.11.012

10. Casey J, Morris K, Narayana M, Nakagaki M, Kennedy GA: Oral ribavirin for treatment of respiratory syncitial virus and parainfluenza 3 virus infections post allogeneic haematopoietic stem cell transplantation. Bone Marrow Transplant. 2013, 48:1558-61. 10.1038/bmt.2013.112

11. Marcelin JR, Wilson JW, Razonable RR: Oral ribavirin therapy for respiratory syncytial virus infections in moderately to severely immunocompromised patients. Transpl Infect Dis. 2014, 16:242-50. 10.1111/tid.12194

12. Trang TP, Whalen M, Hilts-Horeczko A, Doernberg SB, Liu C: Comparative effectiveness of aerosolized versus oral ribavirin for the treatment of respiratory syncytial virus infections: A single-center retrospective cohort study and review of the literature. Transpl Infect Dis. 2018, 20:e12844. 10.1111/tid.12844

13. Chakrabarti S, Collingham KE, Holder K, Fegan CD, Osman H, Milligan DW: Pre-emptive oral ribavirin therapy of paramyxovirus infections after haematopoietic stem cell transplantation: a pilot study. Bone Marrow Transplant. 2001, 28:759-63. 10.1038/sj.bmt.1703216 